(v) protection and conservation, and (vi) global network (Guidelines and Criteria for National Geoparks Seeking UNESCO's Assistance to Join the Global Geoparks Network (GGN April 2010) (Figure 1)

FIGURE 1: Criteria for Geopark

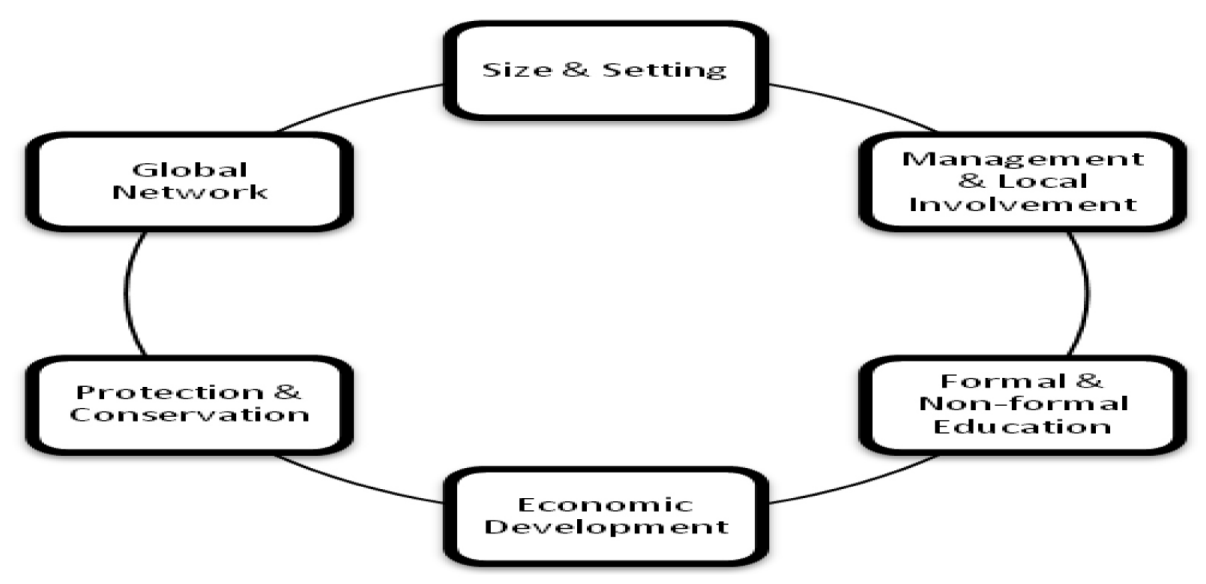

Figure 1 shows that the geopark concept highlights the potential interaction between socio-economic and cultural development and conservation of the natural environment (Mohd Shafeea Leman et al. 2007:95), thus providing opportunities to achieve a more balanced development between geoheritage conservation and local socio-economic development. In other words, as a sustainable development tool the geopark concept ensures balance between three main elements, namely conservation of heritage resources; development of tourism industry and infrastructure; and enhancement of local participation (Ibrahim Komoo \& Patzak 2008). This form of sustainable economic development in areas with rich geological and biological resources has the potential to directly impact on those rural areas that have suffered from economic stagnation or demographic decline (McKeever 2009:7) and could lead to job creation in local rural communities for their own benefit. However, in order to achieve the balance there need to be integrated natural and cultural heritage conservation. As shown in Figure 2, prerequisites to the development of geoparks are three components namely: heritage conservation, economic development and community development. Geopark seeks to conserve significant geological and landscape features, biological as well as cultural and community resources in order to maintain their symbiotic relationships.. Its purpose and goal are three-pronged: conservation, education and geotourism.

In order to achieve the objectives the management of geopark need to educate and communicate geoscientific knowledge and environmental conservation needs and concepts to the public and to enhance public awareness. Geopark also emphasises on 
public participation and involvement in economic activities such as geotourism. Cultural and natural heritage are the selling points of a geopark and forms part of the key factors to stimulate local socio-economic development. By attracting increasing numbers of visitors, a geopark stimulates local socio-economic development through the promotion of a quality label linked with the local natural heritage. It encourages the creation of local enterprises and cottage industries involved in geotourism and geoproducts, thus contributing to the capacity building of the local community.

In a nutshell, geopark is more than just to protect and conserve the natural heritage especially the geological, it also acts as a development tool. Geopark emphasises local community participation for socio-economic development, especially geotourism. These concepts are in line with the concept and principles of sustainable development, which aims for a balance between social wellbeing, economic development and environmental conservation. Sustainable development concept creates the opportunity for all stakeholders in the geopark to aim at ensuring long-term prosperity and quality of life for future generations.

FIGURE 2: Geopark Development Framework: Balance between Need for Conservation, Economic Development and Community Development/Wellbeing

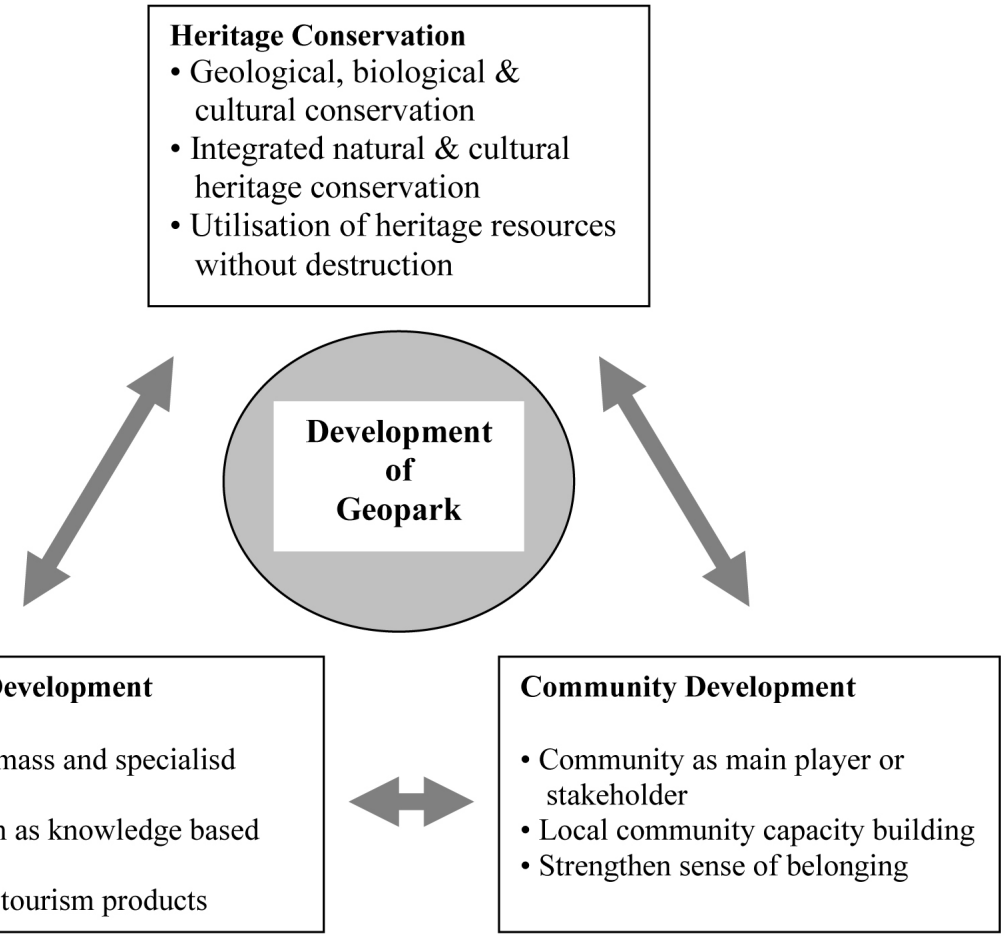

Source: Adapted from Ibrahim Komoo 2010:13 


\section{INTEGRATED PLANNING AND MANAGEMENT FOR GEOPARK}

The multifaceted features and resources of a geopark have to co-exist in a compatible manner if it is to be sustainably managed and for the geopark to achieve its objectives. This means that all stakeholders and affected or relevant public departments and agencies need to be brought to a common platform to enable planning to be done in an integrated way from the national to the local level. The objective is to examine all economic, social and environmental costs and benefits in order to determine the most appropriate option for action. Integrated planning and management is the effective management of resources through collaboration of efforts and cooperation of the various entities in order to meet conservation purposes and at the same time to provide the public with tangible community benefits.

It is increasingly recognised that planning, management and regulation are important at the local level. Environmental and socio-economic conditions vary greatly from locality to locality even within the same region. There are many different stakeholders - public sector, private sector, non-governmental organisations (NGOs), local communities - and they give heritage different values, functions, roles, ranking and as such can suggest different conservation strategies and actions (Halimaton Saadiah Hashim 2011). The different stakeholders are becoming increasingly important in heritage management and planning, especially the community as owner and custodian of heritage (Nuryanti 1996; Peters 1999). It is crucial that the community be involved to increase the quality of planning and reduce the likelihood of conflict. Through education and other awareness creating campaigns community sense of ownership of its heritage could be increased and its trust in heritage management enhanced (Hall \& McArthur 1998). Also, national and regional policies are important, but local communities are the most aware and best able to respond with the optimal use of local resources (United Nations 2001:24).

Most heritage places include more than one kind of heritage and each of the different types needs to be understood. Also each kind of heritage - such as archaeology, geology, biodiversity, buildings - that might be important in its own right - for example a geological monument, a site of special scientific interest, or a listed building - may need different plans and methods for conservation and management. As such having one single plan avoids the need for different plans for different kinds of heritage. It would require careful planning, systematic implementation of the plans as well as continuous and effective management.

The above planning system, which encompasses different plans at the different levels of government need an integrated approach that considers environmental, socio-economic and cultural, institutional and financial aspects, when formulating strategies, programmes and projects. The integrated approach requires the involvement, 
participation and comprehensive cooperation between the various institutions and stakeholders and the creation of partnerships between the public and the private interests at the national, regional and local levels. Planning is an activity of both government and business while integrated planning is one of several management approaches used to address the increasing complexity resulting from complex interaction of many variables (United Nations 2001:19). This integrated approach to planning and development calls for a multidimensional approach to address the complexity of the various perspectives involved and to achieve a relatively balanced evaluation of resources, constraints, needs etc. This is to enable successful planning and management as well as guarantee social acceptance. A single integrated plan may also help to avoid potential conflicts in managing different kinds of heritage by helping the different stakeholders understand what is important about each of them, in relation to each other.

The most important challenge for sustainable development concerns the perspective and expectations that all stakeholders, particularly government policymakers, have about heritage conservation's contribution at the local, regional and national levels. There can be both positive and negative effects from heritage conservation that planners, managers and policymakers need to better understand.

\section{LANGKAWI GEOPARK: GOVERNANCE, PLANNING \& MANAGEMENT}

Langkawi, encompassing historical sites (examples: Mahsuri Mausoleum, Field of Burnt Rice), geological wonders (examples: limestone pinnacles, Pulau Ular geological monument, Lake of Pregnant Maiden, Gua Kelawar), beautiful natural landscapes (examples: stretches of sandy beaches, Machincang mountains, karst landscape, Pulau Anak Burau, Lubuk Semilang waterfall) and a wealth of local culture and traditions (examples: Malay traditional houses, Mek Mulung theatre), is one of the well-known Malaysian tourism island destinations. The island possesses rich geodiversity in terms of rocks, minerals, fossils, geological structures, geomorphological and landscape features, with heritage value of national and regional significance (Mohd. Shafeea Leman et al.. 2007). There are more than 90 geoheritage sites that have been identified throughout Langkawi Geopark (Mohd. Shafeea Leman et al. 2007), some of which have been proposed to be included in the National Geological Heritage List. These special features need to be protected, conserved, and managed in a sustainable manner so that they could still be appreciated, valued and enjoyed as well as benefit present and future generations. In June 2007 the whole of Langkawi's 99 islands, covering a total area of 478 square kilometres, was recognised as a Malaysian geological heritage, accorded a global geopark status by Global Geopark Network GGN and endorsed by UNESCO (Mohd. Shafeea Leman et al. 2007). It is the first geopark in Malaysia and Southeast Asia to be recognised as such. It is also the only geopark in the world with a duty-free status. 
The establishment of the Langkawi Geopark marks an important milestone both in the pursuit of geoheritage conservation and the enhancement of nature's aesthetic tourism potential (Mohd. Shafeea Leman et al.. 2007:3). It also provides the opportunity to combine the geological sites with tourism which can lead to the sustainability of both. In fact as a geopark Langkawi could enhance its ability to fulfill the following targets: (1) achieving sustainable development where nature conservation is given top priority; (2) multiplying tourism products based on value-added knowledge that in turn is based on k-tourism; (3) increasing the capacity of the local community which is essential in driving its sustainable socio-economic development; (4) making Langkawi the nation's leading nature education and research destination (Mohd Shafeea Leman 2007: 96).

As a geopark, and because of its multifaceted features and resources Langkawi Geopark island needs its own system of governance, its own management body. 'Governance' is taken to mean "... the exercise of economic, political and administrative authority to manage a country's affairs at all levels. It comprises the mechanisms, processes and institutions, citizens and groups through which they articulate their interests, their exercise legal rights, obligations and mediate meet their differences..." (UNDP $1997 \mathrm{in} \mathrm{http://}$ mirror.undp.org.magnet/policy). Langkawi Geopark require a governance system that would focus on the need to balance the various demands, bringing together the various stakeholders and interests and shows the direction that guides the development process (Rahimah Abdul Aziz 2011). Research on the governance of Langkawi geopark conducted between 2008-2010 shows that there are many stakeholders directly or indirectly involve with the development of Langkawi Geopark in particular. The stakeholders include the various ministeries at the federal level, namely the Ministry of Finance, Ministry of Tourism and the Ministry of Rural Development and Langkawi Development Authority (LADA); the Kedah state agencies such as the State Forestry Department, State Town and Country Planning Department, and State Fisheries Department and the local agencies (Langkawi District Office, and Langkawi Tourism City Council). These entities are with their various legal mandates and responsibilities. Besides these stakeholders, are the private sector, the various environmental and conservation concerned non-governmental organisations (NGOs), and the local communities and individuals.

Although in general the stakeholders share a common desire to see Langkawi develop and prosper in a sustainable manner, at the same time each stakeholder has its own interests, purposes and objectives. Each stakeholder has its authority, and different zone of influence. However, under the global geopark criteria all stakeholders - public, private, NGOs and community - are expected to cooperate in the efforts to design, plan, manage and implement measures to conserve and develop heritage resources for the sustainable development of Langkawi Geopark. In short, the governance of Langkawi Geopark is related to the implementation of authority held by the various stakeholders in the efforts to conserve heritage resources and implement sustainable economic development on the island. 
Malaysia operates on a federated system of government or a 3-tiered government system. Within the context of governance of Langkawi Geopark, the stakeholders are not only at the local and state levels, but also at the Federal level. While the Federal Government provides budget allocations for the development of Langkawi, the State Government has jurisdiction over the administraion of land and the Langkawi District Office overseers the development that is taking place on the islands. With the involvement and responsibility of the Federal Government, State Government, local authorities, and various other stakeholders, the issue of governance for heritage conservation has become complex because of the involvement of many parties and interests.

Various stakeholders in turn require an effective system of governance if Langkawi Geopark is to maintain or ensure its sustainability. This is because governance has the ability to: (a) bring together the various stakeholders and interests, which is essential for the success of Langkawi Geopark other than to achieve sustainable development; (b) address the need to balance the many different demands; (c) design an ideal pattern of relationships to help realise the connectivity of the various stakeholders; and finally (d) show the direction towards sustainable development. Thus, it is necessary to convert the form of management that encompasses many different authorities to a form of management that has only one party in order to avoid fragmented, overlapping and decentralised directives.

The importance of integrated planning, in particular land use planning, for sustainable development have been acknowledged by the Brundtland Commission (WCED 1987). This is further endorsed in Agenda 21 (WCED 1992). Since then, sustainable development through land use planning, or planning for sustainable development, has been widely debated. Land use planning procedures and processes have expanded leaps and bounds to be more comprehensive in terms of planning considerations and planning inclusiveness. However the biggest asset of land use planning for sustainable development is its comprehensive aspects that are included as planning considerations and planning criteria.

Within the Malaysian land use planning system, integrated planning is institutionalised via the National Physical Pelan (NPP) at the federal level, structure plans at the state level and local plan and special area plan at the local level. The Town and Country Planning Act 1976 (TCPA 1976), replaces the comprehensive development plan system enforced before 1976. The development plan system thus becomes the planning instrument, which determine land use and land development that take into consideration environmental (geological and biological components), social, economic and cultural elements. Land use plans therefore complement the geoparks management plans.

A typical structure plan and local plan for instance covers an average of sixteen or even eighteen aspects or sectoral studies. The outcome of these studies, in the form of policies, 
strategies, land use zones, development projects and development guidelines, have to be assessed to ensure compatibility, consistency and sustainability. In Malaysia this is done through strategic impact assessment, sustainability assessment and social impact assessment. At the development control stage, this is done through the development proposal report, traffic impact assessment and many more according to the areas and nature of development proposal. Local plans and special area plans are site specific. Therefore, their preparations have to take into consideration the detailed attributes of the area, making sure that resources are sustainably utilised while protecting and conserving natural, historical and cultural heritage monuments, sites and areas. More detailed site planning and development are monitored and enforced via development control under the planning permission system by local planning authorities under the TCPA 1976.

Participatory planning has long been accepted as a prerequisite for planning for sustainable development. Malaysia too has accepted this concept and has incorporated statutory requirements for public participation and objections in its planning process (TCPA 1976) for state structure plans and local plans and representative consultation for the national physical plan. Stakeholders' engagement in land use planning enhances integrated planning, beside the planning instruments mentioned earlier. Although nonstatutory, other planning agencies, including the Prime Minister's Department, have acquired public consultation exercises in their planning processes. Since participatory planning is a requirement for planning for sustainable development, the initiatives by these agencies are moves in the right direction for Malaysia.

Planning and management of Langkawi Geopark too has been integrated into the planning process. Langkawi's dossier to the GGN and UNESCO made strong references to the Langkawi District Local Plan as a tool for its implementation, since the local plan is for sustainable development and has integrated both development and natural as well as cultural heritage conservation components (Mohd. Shafeea Leman et al. 2007). The Kedah State Planning Committee, in its approval of the project for the preparation of the Langkawi Geopark Management Plan, in its meeting on 26th August 2010, has made a requirement for the management plan to complement the local plan.

The Langkawi Geopark Management Plan that is under preparation now adopts the integrated planning approach. The study encompasses fourteen sectoral studies and four cross-sectoral studies. Stakeholders' participation from government agencies, private sector, non-governmental agencies, teachers, school children and community reprensatives from the six Mukims (administrative sub-districts) of Langkawi are parts of participatory planning for sustainable development. The topics of discussion at these meetings are mainly about the inter-relatedness and the need for complementary roles of development and conservation. The Langkawi District Local Plan is being used as the principal information baseline for analysis and proposals, beside the information from sectoral and cross-sectoral studies. 


\section{CONCLUSION}

Sustainable development is premised on the responsibility of the government and all other stakeholders to ensure that long-term prosperity and the quality of life of both the present and future generations is not placed at risk. The geopark concept is about integrated heritage conservation based on geoheritage resources of national or international significance and with the local communities as the custodians and beneficiaries of the integrated heritage resources. In order to sustain development it is necessary to address various issues that arise in an integrated, comprehensive, and systematic manner. Issues of policymaking, planning, management and the participation of the private sector and all other stakeholders must be addressed in terms of opportunities for actions and possible constraints that may arise and that need to be overcome by concerted efforts.

The establishment of Langkawi Geopark in 2007 marks an important milestone both in the pursuit of heritage conservation, especially geoheritage, and the enhancement of nature's aesthetic and cultural tourism potential. It provides the opportunity to combine the geological and biological sites with cultural tourism in the form of heritage tourism, which can lead to the sustainability of both and subsequently to further enhance socioeconomic development of the local communities.

The success of the geopark depends on integrated planning and management of its natural and cultural assets as well as on integrated actions of the various stakeholders public and private sectors, NGOs, and the local communities. This is because there are multiple mandates applicable to the various aspects that can put heritage conservation into effect. This means that there are multiple government entities, multiple laws and a host of processes and procedures. Therefore, an integrated planning and management approach that could take into account the various stakeholders and various interests without compromising the need for sustainable development is needed. With such complexities as discussed above, the question then is how to 'integrate' and bring the different stakeholders on to the common platform? Which should be the leading agency with enough authority to carry out the responsibility? These are areas for further research that would add value to Langkawi Geopark specifically and heritage conservation generally in Malaysia and globally.

\section{ACKNOWLEDGEMENTS}

This article is part of a research on Governance of Heritage Conservation conducted by a team of researchers headed by Prof. Dr. Rahimah Abdul Aziz. Besides the authors the researchers include Prof. Dr Ong Puay Liu, Dr. Chan Kim Ling @ Geraldine, Dr. Sharina Abdul Halim and Puan Sarah Aziz Abdul Aziz. The team has benefited much from Universiti Kebangsaan Malaysia through research grants UKM-GUPPLW-08-11-048 and UKM-AP-PLW-01-2009 as well as XX-01-2011, a grant from Langkawi Development Authority (LADA). 


\section{REFERENCES}

Becker, E.J.T. and Stiess, I. 1999. Exploring Uncommon Ground: Sustainability and the Social Sciences. In Sustainability and the Social Sciences: A Cross-Disciplinary Approach to Integrating Environmental Considerations into Theoretical Reorientation. Becker E. and John, T., eds. London: Zed Books.

Chambers, R. and Conway, G. 1992. Sustainable Rural Livelihoods: Practical Concepts for the 21st Century. IDS Discussion Paper No. 296. Brighton: IDS.

Freyfogle, E.T. 2006. Why Conservation is Failing and How It Can Regain Ground. New Haven and London: Yale University Press.

Hall, C. M., and McArthur, S. 1998. Integrated Heritage Management. London: Stationary Office.

Howard, P. 2003. Heritage: Management, Interpretation, Identity. London: Continuum. Halimaton Saadiah Hashim. 2011. Integrated Management for Heritage Conservation. Keynote address at the National Symposium Heritage and Conservation 2011 (Simposium Kebangsaan Warisan dan Pemuliharaan 2011), 29 April - 1 May. Kuching, Sarawak.

Halimaton Saadiah Hashim, Rahimah Abdul Aziz, Sarah Aziz Abdul Ghani Aziz and Chan Kim Ling @ Geraldine. 2010. Governans untuk Geopark: Langkawi Geopark sebagai Acuan (trans: Governance for Geopark: Langkawi Geopark as a Showcase). Akademika, 80, 39-54.

Ibrahim Komoo. 2010. Geopark sebagai Peraga Pembangunan Lestari Wilayah (trans. Geopark as a Model for Regional Sustainable Development). Akademika, 80, 9-18. Ibrahim Komoo, and Patzak, M. 2008. Global Geoparks Network: An Integrated Approach for Heritage Conservation and Sustainable Use. In Southeast and East Asia Geoheritage Conservation. Leman, M.S, Reedman, A and Chen, S.P., ed. Bangi: LESTARI UKM. 1-13

Ibrahim Komoo. 2004. Geoheritage Conservation and Its Potential for Geopark Development in Asia-Oceania. In Warisan Geologi Malaysia (trans. Geological Heritage of Malaysia). Mohd Shafeea Leman and Ibrahim Komoo, eds. Bangi: LESTARI, UKM.

McKeever, P.J. 2009. The UNESCO Global Network of National Geoparks: Geological Heritage and Sustainability. LESTARI Public Lecture Series No. 7. Bangi: LESTARI, UKM.

Mohd Shafeea Leman, Kamarulzaman Abdul Ghani, Ibrahim Komoo and Norhayati Ahmad, eds. 2007. Langkawi Geopark. Bangi: LESTARI, UKM and LADA.

Mohd Shafeea Leman, Ibrahim Komoo, Kamal Roslan Mohamed, Che Aziz Ali and Tanot Unjah. 2007. Geopark as an Answer to Geoheritage Conservation in Malaysia - The Langkawi Geopark Case Study. Geological Society of Malaysia Bulletin 53, June, 95-102.

Nuryanti, W. 1996. Heritage and Postmodern Tourism. Annals of Tourism Research, 23, 249-260. 
Peters, H. 1999. Making Tourism Work for Heritage Preservation: Lijiang, A Case Study. In UNESCO and The Nature Conservancy. Yunnan. International Conference on Anthropology, Chinese Society and Tourism, Kunming.

Rahimah Abdul Aziz. 2011. Governance of Langkawi Geopark. Paper presented at the International Seminar for Future Progress of Jeju Island Global Geopark and National Geoparks Network. 28 May. Jeju Island, South Korea.

Rahimah Abdul Aziz. 2008. Kepentingan Governans dan Pendidikan untuk Pemuliharaan Warisan (trans. Importance of Governance and Education for Heritage Conservation). In Dialog Governans dan Pendidikan Pemuliharaan Warisan: Istilah, Konsep dan Konteks (trans. Governance and Education for Heritage Conservation Dialogue). Rahimah Abdul Aziz and Sarah Aziz Abdul Ghani Aziz, eds. Bangi: LESTARI.

Serageldin, I. 1986. Financing the Adaptive Reuse of Culturally Significant Areas. In The Challenge to our Cultural Heritage: Why Preserve the Past. Isar, R., ed. Washington, D.C: Smithsonian Institute Press.

Town and Country Planning Act (TCPA). 1976.

The World Bank. 1991. Managing Development: The Governance Dimension, A Discussion Paper August 29, Washington, D.C: The World Bank. http://www-wds. worldbank.org/external/default/WDSContentServer/WDSP/IB/2006/03/07/000090 341_20060307104630/Rendered/PDF/34899.pdf (15 February 2011).

UNDP. 1997. Governance for Sustainable Human Development: A UNDP Policy Document. http://mirror.undp.org.magnet/policy (10 Februari 2011).

UNESCO. 2000. UNESCO 'Geoparks Programme Feasibility Study' (unpublished report by Division of Earth Sciences for the UNESCO's Executive Board at the 161 st Session in June 2001), Paris: UNESCO.

UNESCO. 2010. Guidelines and Criteria for National Geoparks seeking UNESCO's assistance to join Global Geoparks Network (GGN) (April 2010). http://www. unesco.org/science/earth/doc1geopark/2010guidelines.pdf. (29 September 2010).

United Nations. 2001. Managing Sustainable Tourism Development. ESCAP Tourism Review No. 22. New York.

United Nations Department of Economic and Social Affairs (Division for Sustainable Development). 2009. Agenda 21. (Online).

United Nations Economic and Social Council. 2006. Definitions of basic concepts and terminologies in governance and public administration, Committee of Experts on Public Administration, Fifth Session, New York, 27-31 March 2006, Agenda item 5. http://unpan1.un.org/intradoc/groups/public/documents/un/unpan022332. pdf (10 February 2011).

World Commission on Environment and Development (WCED). 1987. Our Common Future. Oxford: Oxford University Press.

World Commission on Environment and Development (WCED). 1992. Our Common Future Reconvened. Geneva: Centre for Our Common Future. 


\title{
IMPLEMENTING LANGKAWI GEOPARK THROUGH LAND USE PLANNING
}

\author{
Noor Yazan Zainol ${ }^{1}$, Ibrahim Yacob², Mahani Muhammad ${ }^{3}$ \\ and Mariam Tajuddin ${ }^{4}$ \\ Development Planning Division \\ Langkawi Development Authority (LADA) \\ Hapiz Abd Manap 5 and Ikhwan Mohd Said ${ }^{6}$ \\ Geopark Division \\ Langkawi Development Authority (LADA)
}

\begin{abstract}
Development Plans under the Malaysian Town and Country Planning Act 1976 serve as the principal planning instruments in guiding and regulating protection, conservation, use and development of land towards quality living environment. They also act as guides to investment and use of resources and provide frameworks for short and long term investments by public and private agencies, and for the co-ordination of their decisions. Planning and development control at the lowest level then regulates development so that it complies with land use plans. Through land use planning, sustainable development, protection and conservation of natural and cultural heritage resources can be regulated. For Langkawi Geopark, tourism is the most important sector in its economic development. To further enhance and capitalise from this sector, eco-tourism with iconic geo-bio-cultural sites can be promoted through implementing the Geopark concept. This article describes how the geopark concept in Langkawi is implemented through land use planning.
\end{abstract}

Keywords: Development plan, protected areas, geopark, Geoforest Park, sustainable development, ecotourism

\footnotetext{
${ }^{1}$ Manager, Development Planning Division, Langkawi Development Authority (LADA), 07000 Kuah, Langkawi, Kedah, Malaysia. e-mail: nooryazan@lada.gov.my

${ }^{2}$ Assistant Manager, Planning and Development Division, LADA

${ }^{3}$ Assistant Manager, Planning and Development Division, LADA

${ }^{4}$ Assistant Manager, Planning and Development Division, LADA

${ }^{5}$ Manager Geopark Division, LADA, 07000 Kuah, Langkawi, Kedah, Malaysia (until 8 Dec 2011)

${ }^{6}$ Assistant Manager, Geopark Division, LADA
} 


\section{INTRODUCTION}

In Malaysia, land use planning or commonly called town and country planning matters are the concurrent responsibilities of Federal and State Governments under the Federal Constitution. In Peninsular Malaysia land use planning is formally undertaken within the provision of the Town and Country Planning Act, 1976 (Act 172), which has been amended several times to accommodate the evolutionary needs of the rapidly changing environment for more comprehensive and integrated development planning (Khir 2008).

Yeo (2008) acknowledged that it is important to improve the quality of life based on the principle of sustainable development (SD) so that development meets the needs of the present without compromising the ability of future generations to satisfy their own requirements (WCED 1987). In this respect, irreparable damage caused to the natural environment or the depletion of available natural resources must be prevented or remedied, failing which the access of future generations to these resources would be limited and, thereby, their ability to meet their own needs would be compromised. Thus, sustainable development is a social responsibility that demands an interplay between the economy and the environment with the aim of managing both to ensure intra and inter-generational equity. Land use planning has been acknowledged as an effective instrument for implementing sustainable development (WCED 1987, Agenda 21 1992). Among international agreements on the environment which were ratified by Malaysia in relation to land use (Halimaton Saadiah Hashim 2008) include: the Vienna Convention for the Protection of the Ozone Layer 1985, the Convention on Biological Diversity 1992, the Kyoto Protocol to the UNFCC Convention on Biological Diversity 1992, the United Nations Framework Convention on Climate Change (UNFCC) 1997, and the Convention Concerning the Protection of the World Cultural and National Heritage 1989.

Local Agenda 21 (LA 21) is a local level translation of Agenda 21, which is an action plan for the implementation of sustainable development as agreed by 178 member countries of the United Nations at the Rio Earth Summit in 1992. This requires every local authority to draw up its own Local Agenda 21, a strategy and programme for implementing sustainable development towards ensuring a better quality of life for the people in its area. This follows from the argument that the achievement of sustainable development must start from the local level. Like Agenda 21, LA21 should focus on an economic, social and environmental agenda, and develop solutions to problems through encouraging better, more efficient practices.

Malaysian land use planning is implemented through several tools such as the following: 


\section{Development Plans}

The purpose of applying planning principles and standards in land use and physical planning is to create a suitable environment for human habitation. This is done through the application of wide-ranging theories and techniques, and the use of planning principles and standards. Development Plans under the Town and Country Planning Act 1976 (Act 172) comprises the state structure plans and local plans. The plans are to provide adequate infrastructures and utilities, basic public facilities, and other services to satisfy the needs in every aspect of human life within the framework of the overall physical, economic and social development of urban and rural areas, with the main goal of implementing sustainable development. They are tools for comprehensive integrated planning, and in order to create a sustainable living, working and recreational environments, consideration for the environment and environmental resources should be one of the important issues and sectors included in development plans.

The TCPA has been amended several times since 1976. As noted by Muhammad (1994), the revisions to the mandates, scope, procedure and process of preparing Development Plans (structure and local plans) were necessary in the Town and Country Planning system in order to incorporate stronger means of control over the development and management of Protected Areas. He further stressed that this is because land use planning, by definition, is a dynamic activity that requires its legislation to be able to adopt new approaches and adapt to changing needs and situations over time. Specifically, he argued for an additional emphasis on the role of target-setting in plans, and on ensuring their full implementation.

The sustainability agenda has been considered in the Development Plans prepared under the TCPA. The National Physical Plan (NPP) serves as the framework to achieve integrated and sustainable land use planning in the country (FDTCP 1995, 2010). This clearly deals with sustainability through its policies that are directed towards conserving natural resources and the environment, and the need to identify and manage EnvironmentallySensitive Areas (ESAs) which, it is stated, shall be protected and used in a sustainable manner. According to Bruton (2007), the NPP fills the gap between higher order socioeconomic plans and policies and the more detailed plans (tructure and local plans) that are closer to the implementation mechanisms. Bruton also mentioned that the NPP serves as a strategic land use/spatial plan for spatial development on a national scale and lies within the framework of Malaysia Plans, Vision 2020 and Agenda 21.

At the local level, the local plan, serves as an important instrument in shaping the development of an area and as the basis for planning control. The local plan translates all policies outlined in the NPP and the state structure plan to the local level. This is considered a crucial stage where actual interpretation of policies and the agenda for 
sustainability in the form of spatial planning takes place. To ensure that local plans adhere to the principles of sustainability, sustainability assessment (SA) is conducted in the preparation process of every local plan prepared under the Ninth Malaysia Plan. The aim of the SA is to check and guide the preparation of the local plan to ensure compliance with the principles of sustainability. The administrative structure and hierarchy of Development Plans, and the planning control system set a clear framework for all planning activities and decisions in Malaysia.

According to Kleemann (2000) a large number of international initiatives that combine regulatory and incentive instruments are aimed at protecting special areas, and the three categories of combined approach most commonly used in current practice are: integrated coastal zone management (ICZM), special municipal programmes, and efforts that promote sustainable local development such as eco-tourism. Regulatory and incentive approaches should always be combined in such a way that they resolve the key threats to protected areas.

Since distinctive and characteristic landscapes make major contributions to national, regional and local identity, it is common for such areas to receive some form of official protection either through planning safeguards or conservation management. The benefits of participatory management in land care, such as sharing responsibilities and negotiating benefits highlighted by Selman (2004), are gained by the incorporation of wide-ranging professional knowledge that: enhances the capacity for implementation, increases trust between stakeholders, reduces the deadweight of enforcement, improves understanding and awareness, facilitates policy integration, and increases public commitment.

In order to implement effective planning and management strategies for protected areas, an integrated and comprehensive environmental management policy within the Development Plans is vital (Noor 1999). Such a system will definitely help in the decision-making process during processing planning applications for change of landuse, preparing Development Plans, and in development control and planning decisions made by State, and Local Planning Authorities (LPAs).

\section{Development Control}

The objective of development control is to ensure that development would take place as envisioned by the development plans, including land use zoning, intensity of use, allocating adequate open space, and providing infrastructure and community facilities. Local plans form the detailed basis for this activity. Every instance of land development requires planning permission from the local authority,which is the local planning authority (TCPA 1976), and this involves the assessment of the specific development proposal to establish whether or not it conforms to the local plan for the area. Protected 
areas that are located within a local planning authority area and covered by gazetted development plans incorporate clear and strong development control guidelines.

Sustainability is the ultimate vision in land use planning. Therefore, sustainability assessment (SA) is applied to ensure that sustainable development is treated in a comprehensive manner in a local plan. This is especially so in examining the relationship between the social, environment and economic needs, which must be sustainably balanced and integrated. The SA in a local plan is an assessment process which identifies the compatibility of proposals and their impacts on the sustainability objectives of that plan. In the SA process, sustainability indicators are designed for the study area and are used to benchmark current sustainability status, and to identify gaps or deviations from comparators and sustainability targets, thus facilitating problem-solving for the study area. Sustainability indicators include all environmental, social, economic and physical aspects of the local plan. Eventually, these indicators can be used as a monitoring tool to examine the performance of the local plan in relation to its sustainability targets.

The current planning process in Malaysia has not been developed to a stage where it can properly accommodate the concerns of environmentalists, and at this point it is appropriate to outline its operation, since the identification of gaps in powers, integration and coordination with other professionals, will demonstrate where some of the difficulties lie.

The planning of physical land use is important since it has the potential to sustain or destroy protected and conservation areas, in light of the fact that protected areas and planning for such areas are closely linked to areas around them. Obviously, the creation of protected areas and the identification of conservation areas is a pointless exercise if the nature reserves in question are going to be gradually eroded away by external forces. In this respect, physical land use planning does not only present a means for containing such threats, but it may also contribute to site planning and management of protected areas.

\section{Development Plan and Protected Areas}

In attaining environmental goals, total integration is an ideal. Consequently, management and decision-making must move towards greater integration through interaction between all involved sectors, and that must include participation by the public and co-ordination among stakeholders (Margerum and Born 2000). Many of the elements of an integrated approach are already in place, but they need to be more widely applied, further developed and strengthened (UNEP 2000). According to Cullingworth (1999), planning authorities have a duty to determine which parts of their areas are of special architectural or historic interest, such that their character must be preserved or enhanced, and also to designate such areas as protected. When a protected area has been designated, special attention 
must be addressed in all planning decisions to the preservation and enhancement of its character and appearance.

Two approaches to determine development in protected areas are outlined by LESTARI (1999). The first approach emphasises controlling development through the application of development standards to ensure minimal negative impact. This strategy assumes that development proposals are made from outside the system, and the planning task is to ensure that the development to be implemented will not damage the environment, to the detriment of residents and consumers of the area. The second approach involves indicating proactive development trends within the protected area. Both these approaches involve radical actions as part of which there is a role for the Planning Authority and administrators in identifying trends and specific projects for the area.

Development Plans can make a significant contribution towards creating a sustainable local environment. In fact, environmental problems would not have reached such an alarming stage in developed areas, if such plans had been properly prepared and seriously implemented (Halimaton Saadiah Hashim 1994). Environmental planning and management of local resources must be carefully formulated and based on a good environmental understanding, environmental appraisal, and social and physical land use characteristics of the local planning area. Any changes projected are likely to have effects on the development of the planning area.

Local Planning Authorities (LPAs) that are entrusted with planning, development control, and cleansing functions of their areas, must be the first line of defence against destruction of the environment in their area of jurisdiction. In fact, they are in the best situation to ensure that efforts are made to reduce environmental degradation and that the aspirations of the community in creating a sustainable built environment are met. They are also empowered to perform duties which are specifically authorised by law under the Local Government Act 1976 (Act 171) and the Street, Building and Drainage Act 1974 (Act 133). As such, the local planning authority has the power to prepare local plans, which are the lower level plan in the strategic hierarchical system of development plans (the state structure plans are the upper level plan), that are environmentally sustainable and to reject development projects that are deemed to be environmentally hazardous or damaging. The process of physical land use planning is a continuous activity of evaluating and compromising the conflicting needs of various land uses and activities which are the basic planning tool in the development plan, and which displays how land is to be allocated between various needs and distributed in spatial terms. This is done through the traditional and time-tested planning technique of land use zoning (Cullingworth and Nadin 2002). Land use zoning is supported by planning policies, which articulate related 